\title{
Stand density index as a predictor of forage production in northern Arizona pine forests
}

\author{
MARGARET M. MOORE AND DALE A. DEITER
}

\begin{abstract}
Authors are assistant professor and former graduate research assistant; School of Forestry, Northern Arizona University, Flagstaff 86011 . Deiter's present address: Bonner's Ferry Ranger District, Bonner's Ferry, Idaho 83805.
\end{abstract}

\begin{abstract}
Ponderosa pine (Pinus ponderosa Laws.) overstory-forage understory relationships were studied on the Kaibab Plateau of northern Arizona to evaluate how well forage (graminoid, forb, and current year shrub) production could be predicted by stand density index (SDI). Linear and nonlinear equations were used. Stand density index, a relative measure of stand density, was a useful predictor of understory production for a variety of stand structures and ages. The linear and nonlinear equations produced coefficient of determinations of 0.76 and 0.72 , and standard error of the estimates of $5.08 \mathrm{~kg} \mathrm{ha}^{-1}$ and $5.51 \mathrm{~kg} \mathrm{ha}^{-1}$, respectively.
\end{abstract}

Key Words: Plant production, overstory-understory relationships, Pinus ponderosa, stand density measures

Many equations used in predicting forage (graminoid, forb, and shrub) production as a function of ponderosa pine (Pinus ponderosa Laws.) forest overstory have expressed overstory as basal area, an absolute measure of stand structure, and canopy cover (Pase 1958, Reynolds 1962, Pearson 1964, Ffolliott and Worley 1965, Clary and Ffolliott 1966, Jameson 1967, Clary 1969, McConnell and Smith 1970, Ffolliott and Clary 1974 and 1975, Clary et al. 1975, Ffolliott 1983, Bennett et al. 1987, Wilson 1987, Uresk and Severson 1989, Tapia et al. 1990). These studies used inverse linear and nonlinear models expressed as decreasing herbage production with increasing forest overstory and have found basal area and canopy closure to be highly correlated with forage and herbage production.

Additional knowledge of stand structure is necessary, however, to interpret what effect a given tree basal area will have on forage production. In the Southwest, for example, a ponderosa pine stand with a basal area of $10 \mathrm{~m}^{2} \mathrm{ha}^{-1}$ would be open and park-like in stands composed of large mature trees. Forage production below such a stand would likely be greater than in a stand with the same basal area composed of many small-diameter stems. Predictions of forage production may be improved if the expression of tree density incorporated additional stand structural information. Therefore, relative measures of stand density which relate absolute stand attributes to stand structure are attractive for use in predicting forage production.

Stand density index (SDI) is commonly referenced in the literature for use in prescribing tree stocking levels (Stout and Larson 1988, Edminster 1987) and describing wildlife thermal and hiding cover (McTague and Patton 1989); however, to our knowledge it has never been used as a predictor of forage production. The objective of this paper is to demonstrate that stand density index is also a reliable predictor of forage production.

\section{Stand Density Index}

\section{Methods}

Stand density index, as developed by Reineke (1933) is a relative

Research was funded in part by McIntire-Stennis Grant No. 28. The authors wish to thank the anonymous reviewers for their very helpful comments.

Manuscript accepted 6 August 1991. measure of stand density that provides a relationship between trees per hectare, stand basal area, average stand diameter, and stocking of a forested stand. Reineke noted that the $\log$ of trees per hectare when plotted against the log of quadratic mean diameters (the stem diameter of average basal area) took on a negative linear form that had a slope of -1.605 . This relationship is considered analogous to the biological $-3 / 2$ self-thinning power law (Yoda et al. 1963). In application, it is assumed that an increase in quadratic mean diameter of fully stocked stands can only occur if accompanied by a decrease in number of trees per hectare. The functional form of this relationship is:

$$
\log _{10} N=k-1.605\left(\log _{10} Q M D\right)
$$

where, $\begin{array}{ll}\mathbf{N} & =\text { number of trees per hectare, } \\ \mathbf{k} & =\text { a species specific constant, } \\ \text { QMD } & =\text { quadratic mean diameter. }\end{array}$

Stand density index is defined by imposing the condition that SDI equals the number of trees per hectare when quadratic mean diameter is equal to 25.4 centimeters. McTague and Patton (1989) give an excellent discussion of the derivation of stand density index and present Reineke's SDI in the following form:

$$
\mathrm{SDI}=\mathrm{N}(\mathrm{QMD} / 25.4)^{1.605}
$$

where, $\mathbf{N} \quad$ = number of trees per hectare,

$\mathrm{QMD}=$ quadratic mean diameter,

$25.4=\mathrm{a}$ reference $\mathrm{QMD}$,

$1.605=$ a self-thinning constant from Reineke (1933).

Other self-thinning constants have also been suggested for ponderosa pine (Larson 1968, Edminster 1987), however, these equations can be written in the same functional form as equation 2 :

$$
\begin{aligned}
& \mathrm{SDI}=\mathrm{N}(\mathrm{QMD} / 25.4)^{1.891} \\
& \mathrm{SDI}=\mathrm{N}(\mathrm{QMD} / 25.4)^{1.660}
\end{aligned}
$$

where, $N, 25.4$, and $\mathrm{QMD}$ were defined previously.

\section{Study Area}

Our study area consisted of ponderosa pine stands within 4 townships (between latitude/longitude: $36^{\circ} 30^{\prime} 00^{\prime \prime} \mathrm{N} 112^{\circ} 15^{\prime} 00^{\prime \prime} \mathrm{W}$, $36^{\circ} 45^{\prime} 00^{\prime \prime} \mathrm{N} 112^{\circ} 30^{\prime} 00^{\prime \prime} \mathrm{W}$ ) on the North Kaibab Ranger District on the Kaibab National Forest. This district is located north of Grand Canyon National Park in Coconino County, Arizona.

The primary overstory species of the study area are ponderosa pine with clumps of gambel oak (Quercus gambelii Nutt.) scattered throughout. Rocky Mountain juniper (Juniperus scopulorum Sarge.) is occasionally present. The graminoid understory is dominated by 2 species of bluegrass ( Poa fendleriana Steud. Vasey., and Poa longiligula Scribn. and Williams) and bottlebrush squirreltail (Sitanion hystrix Nutt.). The most common forbs include several species of lupine (Lupinus spp.). Buckbrush (Ceanothus fendleri 
Gray.) and Oregon grape (Berberis repens Lindl.) are the major shrub species.

The climate for the Kaibab Plateau is characterized as cool and subhumid. Mean annual precipitation ranges from 50 to 62 centimeters $(\mathrm{cm})$ with a mean of $56 \mathrm{~cm}$. Approximately $55 \%$ of this moisture falls during the late fall and winter months (October to March). Mean annual air temperature ranges from 4 to $6^{\circ} \mathrm{C}$. The average frost-free period is 100 days (Schubert 1974). Elevation of the plots varied from 2,250 to 2,500 meters.

The soils are derived from limestone parent material of the Kaibab formation. The study plots were located on the most common soil subgroups of the Kaibab Plateau-Mollic and Typic Eutroboralfs (USDA Forest Service 1986).

\section{Sampling Design}

Understory and overstory characteristics were measured on 93 study plots in pine stands that ranged in age from 70 to 250 years; average number of stems per hectare was 322 , ranging from 0 to 1200 ; and average quadratic mean diameter $(\mathrm{cm})$ was 37 , ranging from 0 to 92 .

All study plots were located on areas that were harvested at least 10 years prior to sampling since a study by Reynolds (1962) on the Kaibab Plateau shows that this 10 -year period should be a sufficient time since harvest to negate the "harvest effect" on the understory.

Line transects were established within each stand and plot data were collected at 60.4-meter (3-chain) intervals along the transects. The transect length and number of transects within a stand and the number of plots along each transect varied with stand size. Each overstory fixed plot was 400 square meters $(20 \times 20 \mathrm{~m})$. Tree species and diameter at breast height $(\mathrm{dbh})$ were recorded for each tree inside the plot.

Initial sampling failed to produce a sufficient number of plots of low tree density. Therefore, 10 additional plots were taken in the low densities (e.g., $0-30 \mathrm{~m}^{2}$ basal area) to ensure adequate estimation of this critical portion of the response function.

To determine understory standing crop three $0.5 \times 2.0$ meter $(1$ $\mathrm{m}^{2}$ ) understory quadrats were sampled for each overstory plot. This shape was chosen to reduce variation caused by natural patchiness of the understory vegetation. These understory quadrats were located 2 meters from plot center and were oriented $120^{\circ}$ apart.

All current-year's standing crop of grass, sedge, and forb was clipped to ground level and separated into plant type for each understory plot. Grasses were also separated into cool and warm season components. Current-year twig growth below 1.37 meters was clipped on shrubs. Understory data were collected between 22 August and 23 September 1988. Plant samples were oven dried at $70^{\circ} \mathrm{C}$ and were reported on a $\mathrm{kg} / \mathrm{ha}$ basis.

After summing yields in each quadrat and converting to kilo- grams per hectare, average yield from the 3 quadrats was used to develop relationships between forage yield and SDI for that overstory plot.

\section{Statistical Procedures}

Simple linear and nonlinear regression procedures were used to develop forage production models using stand density index. Residuals were plotted for all regression equations to check for systematic lack of fit and violations of regression assumptions. These revealed that variance increased with the untransformed dependent variable (i.e., understory production) response with decreasing overstory density. Hence, a square-root transformation (Weisberg 1985) was applied to the dependent variable for all of the overstory-forage production models presented. All analyses were conducted at the 0.05 alpha level.

\section{Results}

Forage production averaged $441 \mathrm{~kg} \mathrm{ha}^{-1}$ and ranged from 7 to $2,111 \mathrm{~kg} \mathrm{ha}^{-1}$. The mean SDI was 459 , with a range of 0 to 1,274 and a standard deviation of 296 .

The relationship between tree overstory density and forage production for SDI was negatively sloped and curvilinear. This concave function was expected since the understory was graminoid and forb dominated (Clary 1987). A square-root transformation was used to stabilize understory production variance; however, the transformation also changed the form of this relationship by making the shape of the curve less concave compared to a graph of the untransformed data. In high stand densities, the relationship between tree overstory density and understory production was weak or asymptotic (i.e., approximately a horizontal line). This condition was prevalent with decreasing stand density to a threshold where forage production (transformed) increased approximately linearly with continued decreasing overstory density.

\section{General Model Comparison}

The piece-wise linear model $(Y=$ Intercept + Slopel $(D)+$ Slope2 $\left.(D-B r e a k)^{*} X\right)$ and the nonlinear model $\left(Y=a+b * \exp ^{-c * D)}\right.$ were both suitable for approximating the relationship between overstory density and forage production for SDI; where, $\mathrm{Y}=$ square root of understory production (oven-dry $\mathrm{kg} \mathrm{ha}^{-1}$ ), $\mathrm{D}=$ stand density index (SDI), $X=1$ if D $>$ BREAK, 0 otherwise, exp = base of natural logarithms, and a,b,c are coefficients to be determined.

Initially, semi-log and log-log transformations were used because models are reported most often in the literature for ponderosa pine forests (Ffolliott 1983). Surprisingly, these log models displayed heterogeneous variance and showed signs of systematic lack of fit in this analysis based on examination of the residuals. A squareroot transformation on the dependent variable alleviated these problems. The coefficients of the least-square regression solutions for the piece-wise and the nonlinear models are presented in Table 1.

Table 1. Coefficients, coefficients of determination, and standard errors for the least-square regression solutions of the piece-wise and nonlinear stand density index models.

\begin{tabular}{|c|c|c|c|c|c|c|}
\hline \multicolumn{7}{|c|}{$\begin{array}{l}\text { Piece-wise model: } \\
{ }^{2} Y=\text { Intercept + Slope1(D) + Slope2(D - BREAK)*X }\end{array}$} \\
\hline $\begin{array}{l}\text { Measure (D) } \\
\text { SDI }\end{array}$ & $\begin{array}{l}\text { Intercept } \\
35.770\end{array}$ & $\begin{array}{l}\text { Slopel } \\
-0.0477\end{array}$ & $\begin{array}{l}\text { Slope2 } \\
0.0440\end{array}$ & $\begin{array}{l}\text { BREAK } \\
503.2\end{array}$ & $\begin{array}{l}b^{2} \\
0.76\end{array}$ & $\begin{array}{l}\mathrm{SE} \\
5.08\end{array}$ \\
\hline \multicolumn{7}{|c|}{$\begin{array}{l}\text { Nonlinear model: } \\
{ }^{\mathrm{a}} \mathrm{Y}=\mathrm{a}+\mathrm{b}^{*} \exp ^{(-\mathrm{c} * \mathrm{D})}\end{array}$} \\
\hline $\begin{array}{c}\text { Measure (D) } \\
\text { SDI }\end{array}$ & $\begin{array}{l}\mathrm{a} \\
3.5837\end{array}$ & $\begin{array}{l}\text { b } \\
32.326\end{array}$ & $\begin{array}{l}\mathrm{c} \\
0.0021\end{array}$ & $\begin{array}{l}\mathrm{r}^{2} \\
0.72\end{array}$ & $\begin{array}{l}\text { SE } \\
5.51\end{array}$ & \\
\hline
\end{tabular}

${ }^{a}$ Equation(s): $Y=$ square root of understory production (oven-dry $\mathrm{kg} \mathrm{ha}^{-1}$ ); $\mathrm{D}=$ stand density (SDI) (Reineke 1933); $\mathrm{X}=1$ if D $>$ BREAK, 0 otherwise; exp = base of natural logarithms; a,b,c are coefficients.

r: coefficient of determination; for nonlinear model $=1$ - (RSS/total sum of squares).

${ }^{\mathrm{C}} \mathrm{SE}$ : standard error of the estimate 

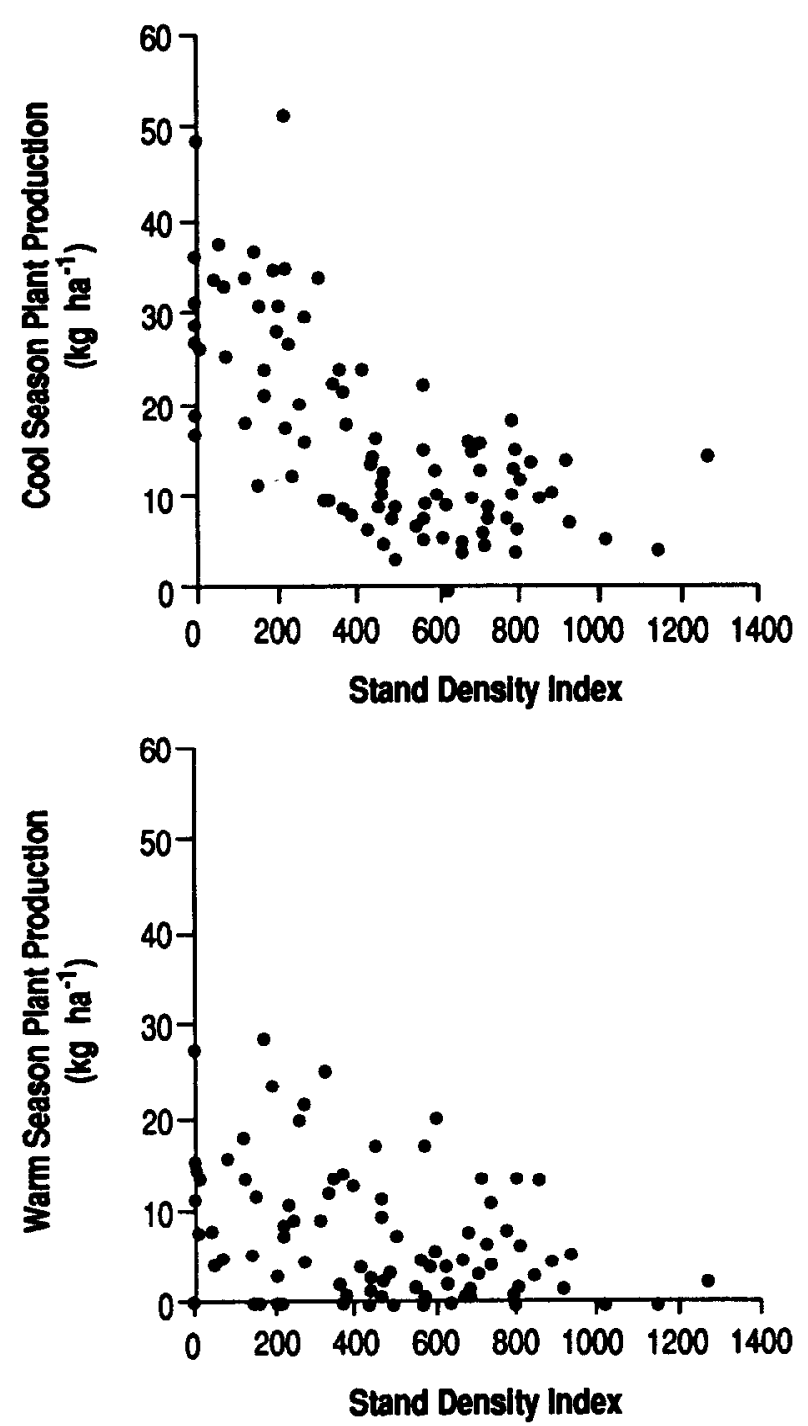

Fig. 4. Cool and warm season plant production $\mathrm{kg} \mathrm{ha}^{-1}$ versus stand density index.

would be possible; however, their plots were grazed by cattle which rendered comparisons with this study inappropriate.

The r-square and standard error values using SDI as a predictor of forage production in this study (Table 1) fall within the range of values presented in several recent articles using basal area $\left(\mathrm{m}^{2} \mathrm{ha}^{-1}\right)$ as the predictor variable (Uresk and Severson 1989, Tapia et al. 1990). These studies were conducted in the ponderosa pine type also. Uresk and Severson (1989) used both simple linear and nonlinear models and obtained r-square values of 70,72 , and $83 \%$, and standard errors of 393,226 , and 379 , for 3 years of data, respectively. Tapia, et al. (1990) used semilogarithmic and polynomial models in their equations and obtained r-square values of 70 and $76.5 \%$, and standard errors of 0.25 and 0.23 , respectively. The point is that using SDI as a predictor of forage production appears to be reliable, it does not appear to be that much more reliable than those using basal area. However, these and other studies are not directly comparable because there are many other factors which influence understory production such as soil quality, precipitation patterns, overstory canopy cover, differences in harvest and slash treatments, and past use which have not been held constant. Therefore, in order to directly compare the merits of each predictor variable, a study needs to be conducted which examines each predictor simultaneously.

\section{Linear versus Nonlinear Models}

The piece-wise linear model and the exponential nonlinear model performed well as general models for predicting understory production. The linear models explained slightly more variation in understory production than did the nonlinear ones. Both models differ in how they mimic the threshold response of forage production in low SDI and the asymptote in high SDI. However, the piece-wise general model is most certainly not the "true" form of the tree overstory-forage understory relationship for 2 reasons.

First, the break point or "kink" of the piece-wise line is not continuous because the first derivatives of the 2 lines at the break point are not equal. Secondly, the piece-wise models are not truly asymptotic as would be expected of the "true" relationship (Neter and Wasserman 1974, Weisberg 1985). Neither of these shortcomings, however, are important for predictive purposes because the piece-wise line is nondisjoint, and the model remains asymptotic for unreasonably large SDI values. Thus, in all other aspects, the piece-wise model seems biologically appropriate for representing the observed relationship.

There are several advantages that can be realized by using the linear piece-wise model rather than the nonlinear ones. Statistically, linear regression is simpler to calculate and more flexible, and the results are easier to interpret than nonlinear regression. The semi-log and $\log -\log$ models can be estimated using linear least-square procedures. However, in instances evident in this study where none of the logarithmic models provide a good fit to the data, the piece-wise general model permits another linear option. A transformation of the dependent, independent, or both variables may be necessary to comply with regression variance assumptions.

\section{Management Implications}

Arizona's pine forests produce quantity of resources simultaneously (timber, forage, water, esthetics) and are a prime place to practice multiple use management. Therefore, an understanding of pine overstory-forage production relationships is important. Also, measurements collected from relative measures of stand density such as SDI (e.g., tree diameter) are often used to drive certain resource models and could reduce the redundancy of data collection in an integrated resource inventory.

In our 1-year study, SDI was a useful predictor of understory production in a variety of stand structures and ages. Although, stand density index was developed for even-aged stands, it may be used for describing density in uneven-aged stands (Stage 1968), for describing wildlife habitat (McTague and Patton 1989), and for predicting forage production, especially when the forage is dominated by grasses.

\section{Literature Cited}

Bennett, D.L., P.D. Lemme, and P.D. Evenson. 1987. Understory herbage production of major soils within the Black Hills of South Dakota. J. Range Manage. 40:166-169.

Clary, W.P. 1987. Silvicultural systems for forage production in ponderosa pine forests. p. 185-191. In: Proc. Ponderosa Pine-The Species and Its Management. 29 Sept.-1 Oct., Spokane, Wash.

Clary, W.P., W.H. Kruse, and F.R. Larson. 1975. Cattle grazing and wood production with different basal areas of ponderosa pine. J. Range Manage. 28:434-437.

Clary, W.P. 1969. Increasing sampling precision of herbage variables through knowledge of the timber overstory. J. Range Manage. 22:200-201.

Clary, W.P., and P.F. Ffolliott. 1966. Difference in herbage-timber relationships between thinned and unthinned ponderosa pine stands. USDA Forest Serv. Res. Note RM-74.

Edminster, C.B. 1987. Stand density and stocking in even-aged ponderosa pine stands. p. 253-260. In: Proc. Ponderosa Pine-The Species and Its Management. 29. Sept. 1 Oct., Spokane, Wash. 
Ffolliott, P.F. 1983. Overstory-understory relationships: southwestern ponderosa pine forests. p. 13-18. In: E.T. Bartlett and D.R. Betters (eds.). Overstory-Understory Relationships in Western Forests. West. Reg. Res. Pub. 1. Colorado Agr. Exp. Sta., Fort Collins.

Ffolliot, P.F., and W.P. Clary. 1975. Differences in herbage-timber relationships on sedimentary and igneous soils in Arizona ponderosa pine stands. Prog. Agr. in Arizona 27:6-7.

Ffolliot, P.F., and W.P. Clary. 1974. Predicting herbage production from forest growth in Arizona ponderosa pine. Prog. Agr. in Arizona. 26:3-5.

Ffolliot, P.F., and D.P. Worley. 1965. An inventory system for multiple use evaluations. USDA Forest Serv. Res. Pap. RM-17.

Jameson, D.A. 1967. The relationship of tree overstory and herbaceous understory vegetation. J. Range Manage. 20:247-249.

Larson, F.R. 1968. A comparison of stand density measurements for ponderosa pine in the Southwest. MS Thesis, Northern Arizona Univ., Flagstaff.

McConnell, B.R., and J.G. Smith. 1970. Response of understory vegetation to ponderosa pine thinning in eastern Washington. J. Range Manage. 23:208-212.

MeTague, J.P., and D.R. Patton. 1989. Stand density index and its application in describing wildlife habitat. Wildl. Soc. Bull. 17:58-62.

Neter,J., and W. Wasserman. 1974. Applied linear statistical models. Irwin Inc. Harwood, Ill.

Pase, C.P. 1958. Herbage production and composition under immature ponderosa pine stands in the Black Hills. J. Range Manage. 11:238-243.

Pearson, H.A. 1964. Studies of forage digestibility under ponderosa pine stands. p. 71-73. In: Proc. Soc. Amer. Forest., Denver, Colo.

Reineke, L.H. 1933. Perfecting a stand-density index for even-aged forests J. Agr. Res. 46:627-638.
Reynolds, H.G. 1962. Use of natural openings in a ponderosa pine forest of Arizona by deer, elk, and cattle. USDA Forest Serv., Rocky Mountain Forest and Range Exp. Sta. Res. Note RM-66.

Schubert, G.H. 1974. Siliviculture of southwestern ponderosa pine: The status of our knowledge: USDA Forest Serv., Rocky Mountain Forest and Range Exp. Sta. Res. Pap. RM-123.

Stage, A. 1968. A tree-by-tree measure of site utilization for grand fir related to stand density index. USDA Forest Serv., Intermount. Forest and Range Exp. Sta. Res. Note INT-77.

Stout, S.L., and B.C. Larson. 1988. Relative stand density: Why do we need to know? p. 73-79. In: Proc. Future Forests of the Mountain West: A Stand Culture Symposium. USFS Intermount. Sta. Gen. Tech. Rep. INT-243.

Tapia, L.A.B., P.F. Ffolliott, and D.P. Guertin. 1990. Herbage production-forest overstory relationships in two Arizona ponderosa pine forests. J. Range Manage. 43:25-28.

Uresk, D.W., and K.E. Severson. 1989. Understory-overstory relationships in ponderosa pine forests, Black Hills, South Dakota. J. Range Manage. 42:230-208.

USDA Forest Service. 1986. Terrestrial ecosystem survey handbook. USDA For. Serv., Region 3, Albuquerque, N.M.

Weisberg, S. 1985. Applied linear regression. John Wiley and Sons. N.Y.

Wilson, M.J. 1987. The effect of harvest intensity on predicting tree basal area increment, volume increment, and herbage standing crop in ponderosa pine. MS Thesis, Northern Arizona Univ., Flagstaff.

Yoda, K., T. Kira, H. Ogawa, and K. Hozumi. 1963. Self-thinning in overcrowded pure stands under cultivated and natural conditions (Intraspecific Competition Among Higher Plants XI). J. Inst. Polytech. Osaka City Univ., Ser. D. 14:107-129. 